\title{
IDENTIFIKASI KONTAMINASI TELUR NEMATODA USUS PADA SAYURAN KUBIS (Brassica oleracea) WARUNG MAKAN LESEHAN WONOSARI GUNUNGKIDUL YOGYAKARTA TAHUN 2010
}

\author{
Cahyono Nugroho, Sitti Nur Djanah, Surahma Asti Mulasari \\ Fakultas Kesehatan Masyarakat, Universitas Ahmad Dahlan, Yogyakarta
}

\begin{abstract}
Background : Vegetables can be eaten by fully or in portion on fresh condition (lalapan) or in be cooked. Fresh vegetables (lalapan) useful for the healthy of our bodies caused have good nutrition that relative high in vitamine and mineral shape, and one kind of that's vegetables is cabbage or kol. Cabbage which have been cleaned may still find the germs agent for example is the intestinal nematode. In Indonesia, intestinal nematode remain caused the serious public health problem, are Ascaris lumbricoides, hook worm and Trichuris trichiura. Soil, vegetables and water are the important one of the transmission way of the eggs of intestinal nematode, if there found many eggs of intestinal nematodes on the contamination sources (like vegetables, soil and the others) automatically will followed with the increasing of endemic degree.

Method : This was descriptive qualitative research using laboratory enclosed. The cabbage that are used for examination materials, cabbage that usually use on food court especially pedestrian food court (warung makan lesehan) which sold on the midle of the city Wonosari Gunungkidul Yogyakarta. To make sediment of the eggs of intestinal nematode is used $\mathrm{NaOH} \mathrm{0,2 \%} \mathrm{solution} \mathrm{as}$ detergent solution. The practice of this exam use sedimentation technique and than be checked the diagnosting on microscope. The result of data that shown on therefore any contamination or yet the eggs of intestinal nematode, the kind of species of intestinal nematode and infective stage of those species. Data will be analyzed in descriptive qualitative statistic and been shown on table and chart.

Result: The result of this research showed that there any contamination of the eggs of intestinal nematode from the cabbage (Brassica oleracea) that was been analyzed (38,89\%), for the species of the eggs of intestinal nematode that shown positive samples are found Ascaris lumbricoides (50\%), hook worm (12,5\%) and Trichuris trichiura (37,5\%). The infective stage that known is only one kind of infective stage that is an infective stage from Ascaris lumbricoides egg.

Conclution: There was any contamination of the eggs of intestinal nematode on the cabbage (Brassica oleracea) that used for fresh vegetable menu (lalapan) on pedestrian food court in the midle of the city Wonosari Gunungkidul Yogyakarta.
\end{abstract}

Keyword: Contamination, Cabbage (Brassica oleracea), The eggs of intestinal nematode.

\section{PENDAHULUAN}

Sayuran merupakan makanan pendamping makanan pokok yang kaya gizi. Di dalam sayuran terkandung protein, vitamin dan mineral. ${ }^{1}$ Hampir semua jenis vitamin dan mikronutrien (terutama mineral) yang penting bagi tubuh terdapat di dalam lalapan. Selain vitamin dan mineral, lalapan memiliki kandungan serat yang tinggi Sayuran yang sering digunakan menjadi lalapan di warung makan lesehan, meliputi timun, kemangi, kacang panjang, kubis atau kol dan tomat. ${ }^{2}$

Kubis banyak mengandung vitamin dan mineral yang sangat dibutuhkan tubuh manusia. Sebagai sayuran, kubis dapat membantu pencernaan, menetralkan zat-zat asam dan memperlancar buang air besar. ${ }^{3}$ Kubis atau kol dikonsumsi sebagai sayuran daun, diantaranya sebagai lalab (lalap) mentah dan masak, lodeh, campuran bakmi, lotek, pecal, asinan dan aneka makanan lainnya. ${ }^{4}$

Kubis yang dicuci bersih kemungkinan besar masih mengandung hama penyakit. Hama lain bangsa moluska dan bangsa nematoda. ${ }^{3}$ Penggunaan sayuran mentah yang langsung dikonsumsi dimungkinkan masih terdapat pencemaran dari bibit penyakit. Penyebaran cacing usus pada makanan sayuran dapat terjadi antara lain karena 
kekurangan pengetahuan pengelolaan dan langkah-langkah pencegahannya dari petani sampai tingkat konsumen. ${ }^{5}$

Prevalensi penyakit cacing yang ditularkan melalui tanah di daerah tropik masih cukup tinggi. Di Indonesia, nematoda usus masih menjadi masalah kesehatan masyarakat adalah Ascaris lumbricoides, cacing tambang, dan Trichuris trichiura. Salah satu sumber penularannya adalah air dan lumpur yang digunakan dalam budidaya sayuran. ${ }^{5}$ Tanah, sayur-sayuran, dan air merupakan media transmisi yang penting. ${ }^{6}$ Kebiasaan defekasi di tanah dan pemakaian tinja sebagai pupuk kebun (di berbagai daerah tertentu) penting dalam penyebaran infeksi. ${ }^{7}$

Kontaminasi (contamination) atau adanya agent menular pada permukaan tubuh, pada atau dalam pakaian, termasuk semua yang berkaitan dengan tempat tidur (beeding), mainan, alat-alat bedah atau baju operasi, maupun benda/zat mati termasuk air dan makanan. ${ }^{8}$

Secara umum terdapat dua cara masuknya nematoda usus dalam menginfeksi tubuh manusia, yaitu melalui mulut dan kulit. Telur-telur tersebut dapat masuk ke dalam tubuh manusia, diantaranya melalui tidak bersih dalam mencuci, sayuran yang tidak dimasak sedangkan dari larva nematoda usus dapat dimungkinkan melalui air yang terkontaminasi. ${ }^{9}$ Penularan kepada hospes baru tergantung kepada tertelannya telur matang yang infektif atau larva, atau menembusnnya larva ke dalam kulit atau selaput lendir. Seringkali larva di dalam telur ikut tertelan dengan makanan. ${ }^{10}$

Data hasil cross-check pemeriksaan kecacingan yang dilaksanakan oleh UPT Laboratorium Kesehatan Dinas Kesehatan Kabupaten Gunungkidul pada tahun 2009, diketahui bahwa dari 200 sampel pemeriksaan ditemukan sebesar 11 persen sampel memberikan hasil pemeriksaan positif mengandung telur nematoda usus, diantaranya adalah telur Ascaris lumbricoides, dan Enterobius vermicularis.

Observasi awal yang dilakukan diketahui terdapat 18 pedagang lesehan di wilayah Kabupaten Gunungkidul, khususnya di seputaran alun-alun dan lingkungan sekitar pusat kota Wonosari yang menggunakan sayuran mentah sebagai bagian dari menu yang disajikan dalam bentuk lalapan khususnya sayuran kubis dimungkinkan memberikan kontribusi terhadap kejadian penyakit yang bersumber dari infeksi nematoda usus.

Beberapa spesies dari nematoda hidup sebagai parasit didalam saluran pencernaan tubuh manusia, dan didalam suatu kasus tertentu kemungkinan juga dapat ditemukan pada faeces (kotoran) manusia. ${ }^{9}$

Manusia merupakan hospes beberapa nematoda usus. Sebagian besar nematoda ini menyebabkan masalah kesehatan masyarakat di Indonesia. Diantara nematoda usus terdapat sejumlah spesies yang ditularkan melalui tanah dan disebut "soil transmitted helminths" yang terpenting bagi manusia adalah Ascaris lumbricoides, Necator americanus, Ancylostoma duodenale, Trichuris trichiura, Strongyloides stercolaris dan beberapa spesies Trichostrongylus. Nematoda usus lainnya yang penting bagi manusia adalah Oxyuris vermicularis dan Trichinella spiralis. ${ }^{7}$

Dalam melakukan identifikasi telur nematoda usus tersebut digunakan metode pemeriksaan cara tidak langsung yaitu dengan teknik sedimentasi atau teknik pengendapan sederhana.Teknik ini memerlukan waktu lama, tetapi mempunyai keuntungan karena dapat mengendapkan telur tanpa merusak bentuknya. ${ }^{11}$

\section{METODE PENELITIAN}

Penelitian ini termasuk jenis penelitian deskriptif kualitatif dengan menggunakan pendekatan laboratorik. Penggambaran dari penelitian yang dilakukan ini yaitu dengan melihat kontaminasi telur nematoda usus yang meliputi ada tidaknya telur nematoda usus, spesies telur nematoda usus dan bentuk infektif atau non infektif dari spesies telur nematoda usus melalui pemeriksaan sayuran kubis yang digunakan sebagai sayuran 
mentah (lalapan) dengan metode sedimentasi pada warung makan lesehan di kota Wonosari Kabupaten Gunungkidul.

Data diuji dan dianalisis secara deskriptif kualitatif dengan menghitung jumlah sampel yang positif mengandung telur nematoda usus dan yang negatif (tidak mengandung) telur nematoda usus kemudian dihitung spesies telur dan bentuk infektif atau non infektif (fertil dan infertil) dari spesies telur nematoda usus dan dihitung prosentase telur nematoda usus yang ditemukan berdasarkan spesies telur, bentuk infektif atau non infektif (fertil dan infertil) nematoda usus dari sampel yang diperiksa. Data disajikan dalam bentuk tabel atau grafik

\section{HASIL PENELITIAN DAN PEMBAHASAN}

\section{a. Hasil Pemeriksaan Kontaminasi Telur Nematoda Usus}

Hasil pemeriksaan mikroskopis terhadap sayuran kubis yang diperoleh dari warung makan lesehan di kota Wonosari diketahui bahwa pada beberapa sayuran kubis yang diperiksa tersebut ditemukan gambaran adanya kontaminasi telur nematoda usus.

Tabel 1. Hasil Pemeriksaan Telur Nematoda Usus Pada Sayuran Kubis (Brassica oleracea) Warung Makan Lesehan Kota Wonosari Gunungkidul Yogyakarta Tahun 2010

\begin{tabular}{|c|c|c|c|}
\hline \multirow[t]{2}{*}{ No } & \multirow[t]{2}{*}{ Contoh uji } & \multicolumn{2}{|c|}{ Telur Nematoda usus } \\
\hline & & Positif (+) & Negatif (-) \\
\hline 1. & K1 & & - \\
\hline 2. & K2 & & - \\
\hline 3. & K3 & & - \\
\hline 4. & K4 & + & \\
\hline 5. & K5 & & - \\
\hline 6. & K6 & & - \\
\hline 7. & K7 & + & \\
\hline 8. & K8 & + & \\
\hline 9. & K9 & & - \\
\hline 10. & K10 & & - \\
\hline 11. & K11 & + & \\
\hline 12. & K12 & & - \\
\hline 13. & K13 & + & \\
\hline 14. & K14 & & - \\
\hline 15. & K15 & + & \\
\hline 16. & K16 & & - \\
\hline 17. & K17 & & - \\
\hline 18. & K18 & + & \\
\hline
\end{tabular}

Tabel hasil pemeriksaan telur nematoda usus pada sayuran kubis tersebut menunjukkan sebanyak 7 sampel (contoh uji) positif terdapat kontaminasi telur nematoda usus atau sebanyak $38,89 \%$ dan sebanyak 11 sampel (contoh uji) atau $61,11 \%$ tidak ditemukan adanya kontaminasi telur nematoda usus. 


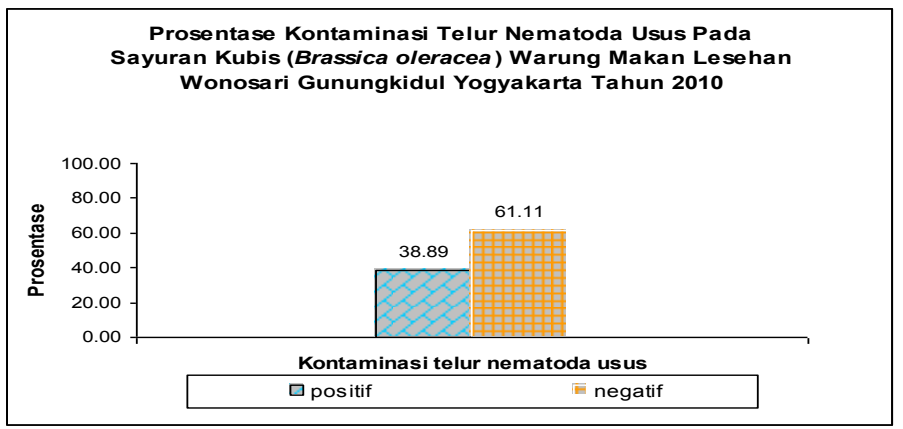

Gambar 15. Grafik Prosentase Kontaminasi Telur Nematoda Usus

\section{b. Hasil Pemeriksaan Spesies Telur Nematoda Usus}

Spesies telur nematoda usus yang ditemukan dari hasil pemeriksaan preparat sedimen yang diperiksa meliputi spesies telur Ascaris lumbricoides, Trichuris trichiura dan cacing tambang sedangkan telur nematoda usus spesies Enterobius vermicularis tidak ditemukan.

Tabel 2. Hasil Pemeriksaan Spesies Telur Nematoda Usus Pada Sayuran Kubis (Brassica oleracea) Warung Makan Lesehan Wonosari Gunungkidul Yogyakarta Tahun 2010

\begin{tabular}{|c|c|c|c|c|c|}
\hline \multirow{2}{*}{ No } & \multirow{2}{*}{$\begin{array}{l}\text { Contoh } \\
\text { uji }\end{array}$} & \multicolumn{3}{|c|}{ Spesies Telur Nematoda Usus } & \multirow[b]{2}{*}{ Enterobius vermicularis } \\
\hline & & Ascaris lumbricoides & Cacing tambang & Trichuris trichiura & \\
\hline 1. & $\mathrm{~K} 1$ & - & - & - & - \\
\hline 2. & K2 & - & - & - & - \\
\hline 3. & K3 & - & - & - & - \\
\hline 4. & K4 & - & - & + & - \\
\hline 5. & K5 & - & - & - & - \\
\hline 6. & K6 & - & - & - & - \\
\hline 7. & K7 & + & - & - & - \\
\hline 8. & K8 & - & - & + & - \\
\hline 9. & K9 & - & - & - & - \\
\hline 10. & K10 & - & - & - & - \\
\hline 11. & K11 & + & - & + & - \\
\hline 12. & K12 & - & - & - & - \\
\hline 13. & K13 & + & - & - & - \\
\hline 14. & K14 & - & - & - & - \\
\hline 15. & K15 & - & + & - & - \\
\hline 16. & K16 & - & - & - & - \\
\hline 17. & K17 & - & - & - & - \\
\hline 18. & K18 & + & - & - & - \\
\hline
\end{tabular}

Hasil pemeriksaan spesies telur nematoda usus pada sayuran kubis, diketahui terdapat beberapa spesies telur nematoda usus. Spesies telur nematoda usus yang paling banyak diketemukan adalah telur Ascaris lumbricoides, pada 4 contoh uji sayuran kubis yang diperiksa, spesies telur Trichuris trichiura, pada 3 contoh uji sayuran kubis yang diperiksa dan spesies telur cacing tambang, pada 1 
contoh uji sayuran kubis yang diperiksa. Dari 7 contoh uji (sampel) sayuran kubis yang diketahui spesies telur nematoda ususnya, sebagian besar merupakan kontaminasi tunggal sedangkan untuk kontaminasi campuran ditemukan pada satu contoh uji sayuran kubis yang diperiksa, yaitu berupa kontaminasi campuran telur Ascaris lumbricoides dengan telur Trichuris trichiura.

Prosentase spesies telur nematoda usus yang ditemukan pada sayuran kubis yang diperiksa dapat ditunjukkan pada grafik berikut :

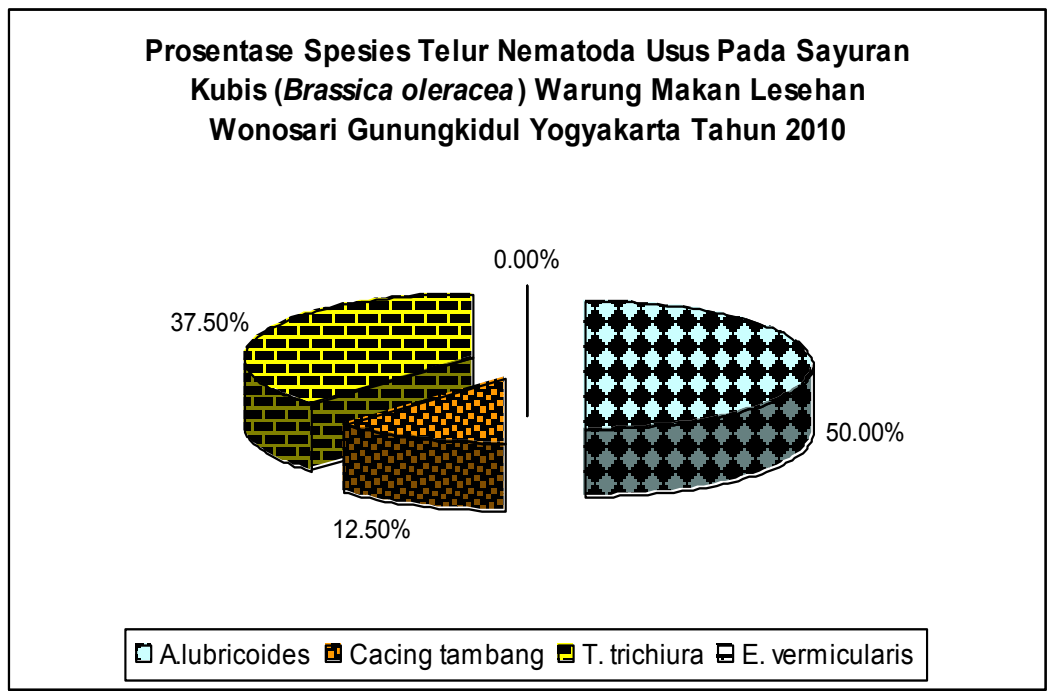

Gambar 16. Grafik Prosentase Spesies Telur Nematoda Usus

\section{c. Hasil Pemeriksaan Bentuk Infektif Telur Nematoda Usus}

Bentuk infektif dari spesies telur yang diketahui memberikan hasil pemeriksaan positif kontaminasi telur nematoda usus pada sayuran kubis yang diperiksa, ditemukan sebanyak 2 buah telur bentuk infektif dari telur nematoda usus spesies Ascaris lumbricoides pada satu contoh uji (contoh uji K7). Data hasil pemeriksaan ditunjukkan pada tabel berikut : 
Tabel 3. Hasil Pemeriksaan Bentuk Infektif Spesies Telur Nematoda Usus Pada Sayuran Kubis (Brassica oleracea) Warung Makan Lesehan Wonosari Gunungkidul Yogyakarta Tahun 2010

\begin{tabular}{|c|c|c|c|c|c|c|c|c|c|}
\hline \multirow{3}{*}{ No } & \multirow{3}{*}{$\begin{array}{c}\text { Contoh } \\
\text { uji }\end{array}$} & \multicolumn{8}{|c|}{ Spesies Telur Nematoda Usus } \\
\hline & & \multicolumn{2}{|c|}{ Ascaris lumbricoides } & \multicolumn{2}{|c|}{ Cacing tambang } & \multicolumn{2}{|c|}{ Trichuris trichiura } & \multicolumn{2}{|c|}{ Enterobius vermicularis } \\
\hline & & Infektif & Non-Infektif & Infektif & Non-Infektif & Infektif & Non-Infektif & Infektif & Non-Infektif \\
\hline 1. & $\mathrm{~K} 1$ & - & - & - & - & - & - & - & - \\
\hline 2. & $\mathrm{~K} 2$ & - & - & - & - & - & - & - & - \\
\hline 3. & K3 & - & - & - & - & - & - & - & - \\
\hline 4. & K4 & - & - & - & - & - & + & - & - \\
\hline 5. & K5 & - & - & - & - & - & - & - & - \\
\hline 6. & K6 & - & - & - & - & - & - & - & - \\
\hline 7. & K7 & + & - & - & - & - & - & - & - \\
\hline 8. & K8 & - & - & - & - & - & + & - & - \\
\hline 9. & K9 & - & - & - & - & - & - & - & - \\
\hline 10. & K10 & - & - & - & - & - & - & - & - \\
\hline 11. & K11 & - & + & - & - & - & + & - & - \\
\hline 12. & K12 & - & - & - & - & - & - & - & - \\
\hline 13. & K13 & - & + & - & - & - & - & - & - \\
\hline 14. & K14 & - & - & - & - & - & - & - & - \\
\hline 15. & K15 & - & - & - & + & - & - & - & - \\
\hline 16. & K16 & - & - & - & - & - & - & - & - \\
\hline 17. & $\mathrm{~K} 17$ & - & - & - & - & - & - & - & - \\
\hline 18. & K18 & - & + & - & - & - & - & - & - \\
\hline
\end{tabular}

Tabel tersebut menunjukkan bahwa spesies telur nematoda usus yang diketahui bentuk infektifnya dari hasil pemeriksaan contoh uji sayuran kubis hanya spesies telur Ascaris lumbricoides, sedangkan spesies telur nematoda usus lainnya walaupun memberikan hasil pemeriksaan positif kontaminasi telur nematoda usus seperti spesies telur cacing tambang dan spesies telur Trichuris trichiura akan tetapi telur yang ditemukan tersebut tidak berupa telur dalam bentuk infektif.

\section{d. Pembahasan}

Hasil analisis dengan menggunakan statistik deskriptif diperoleh gambaran mengenai kontaminasi telur nematoda usus, spesies telur nematoda usus dan bentuk infektif atau non infektif dari spesies nematoda usus tersebut.

1) Kontaminasi Telur Nematoda Usus

Sayuran kubis yang digunakan oleh pedagang warung makan lesehan di kota Wonosari keseluruhannya berasal dari Pasar Argosari Wonosari. Berbagai varietas sayuran kubis yang dikonsumsi oleh masyarakat, didalam pemanfaatannya ternyata jenis sayuran kubis yang digunakan di warung makan lesehan di kota Wonosari yang menjadi subyek penelitian keseluruhannya menggunakan sayuran kubis sub kelompok Kol putih kepala bulat yang masuk kedalam kelompok Kol putih (Brassica oleracea var. Capitata L.f.alba DC) varietas Kubis kepala atau Kol (Brassica oleracea var capitata). Hal ini lebih disebabkan karena didalam pemanfaatannya kubis jenis ini lebih mudah diperoleh dan harganya yang relatif murah. Hasil dari penelitian ini menunjukkan bahwa dari 
18 contoh uji sayuran kubis (Brassica oleracea var capitata) yang diperoleh sebesar $38,89 \%$ memberikan hasil positif terkontaminasi telur nematoda usus.

Hasil penelitian yang dilakukan oleh Bier pada tahun 1991, mengenai isolasi parasit pada buah-buahan dan sayur-sayuran menggunakan metode in vitro, diantaranya digunakan kubis sebagai contoh uji pemeriksaan didapatkan gambaran adanya kontaminasi spesies telur Ascaris sp. dan Trichuris sp. dalam bentuk telur dekortikasi dengan rata-rata pertumbuhan $10 \%$ dari telur yang dibiakkan.

2) Spesies Telur Nematoda Usus

Hasil pemeriksaan sayuran kubis yang memberikan hasil positif tersebut diketahui spesies telur yang terbanyak adalah spesies telur Ascaris lumbricoides $(50 \%)$. Bentuk infektif yang ditemukan pada sediaan preparat yang diperiksa merupakan bentuk infektif dari spesies telur Ascaris lumbricoides, sedangkan spesies telur nematoda usus lainnya, walaupun diperoleh hasil pemeriksaan positif, seperti Ascaris lumbricoides, cacing tambang dan Trichuris trichiura tetapi menunjukkan spesies telur dalam bentuk non infektif.

Dominasi telur Ascaris lumbricoides pada penelitian ini lebih disebabkan oleh sifat dari telur Ascaris lumbricoides yang di dalam tanah tetap hidup pada suhu beku yang biasa terdapat pada musim dingin. Telur tahan terhadap desinfektans kimiawi dan terhadap rendaman sementara di dalam berbagai bahan kimia yang keras. Telur dapat hidup berbulan-bulan di dalam air selokan dan tinja ${ }^{10}$. Tidak ditemukannya telur Enterobius vermicularis kemungkinan dikarenakan oleh sifat dari telur cacing kremi yang penularannya lebih cenderung bersifat retrofeksi, dan kontaminasi pada makanan serta inhalasi telur lewat debu. Daerah penyebarannya yang meliputi kamar tidur, kafetaria, tempat duduk, kakus, kasur dan tilam. Pertumbuhan dan perkembangan telur cacing kremi tidak melalui media tanah secara langsung ${ }^{10}$.

3) Faktor Kontaminasi

Kontaminasi telur nematoda usus yang ditularkan melalui tanah pada sayuran kubis dapat dikarenakan oleh berbagai faktor antara lain adalah faktor alam. Faktor alam meliputi, tanah, iklim, kelembapan dan suhu. Iklim tropik merupakan salah satu hal yang berpengaruh terhadap pertumbuhan dan perkembangan telur nematoda usus, faktor alam lainnya adalah keadaan tanah yang dapat menjadi media perkembangan telur dan kehidupan serta perkembangan larva. Tanah yang subur dan kaya bahan organik yang ditunjang dengan kelembapan dan iklim yang sesuai bagi pertumbuhan sayuran khususnya sayuran kubis juga merupakan faktor adanya kontaminasi telur nematoda usus.

Manusia juga memberikan kontribusi yang cukup berarti terhadap penyebaran infeksi telur nematoda usus. Sanitasi lingkungan yang buruk, sosialekonomi yang rendah, tingkat pengetahuan yang masih kurang dan kebiasaan defekasi di sembarang tempat terutama di lahan pertanian/perkebunan serta kebiasaan kurang bersihnya dalam pengelolaan sayuran di tingkat produsen dan pengolahannya di tingkat konsumen memberikan pengaruh yang cukup signifikan terhadap peningkatan kasus penyakit tersebut.

Hygienitas para pedagang warung makan lesehan terutama hubunganya dengan kebersihan makanan yang disajikan memiliki andil terhadap kualitas makanan yang disajikan, baik kebersihan, kesehatan, maupun nilai gizi. Beberapa faktor yang berpengaruh terhadap kebersihan dalam pengolahan dan pemanfaatan sayuran yang dikonsumsi oleh manusia, seperti cara mencuci sayuran dan teknik mencuci merupakan hal yang perlu diperhatikan. Penggunaan 
air mengalir lebih dianjurkan daripada menggunakan air yang diam (menggenang), seperti air dalam wadah/bak air yang digunakan untuk mencuci sayuran secara berulang. Hal ini dapat berpengaruh terhadap resiko pencemaran oleh berbagai jenis bahan pencemar baik organik maupun anorganik (pestisida) 15

Diperlukan peningkatan kualitas hygientas perseorangan (penjamah bahan pangan) pada pedagang warung makan lesehan serta pemberian bimbingan dan arahan yang berupa penyuluhan kualitas kesehatan makanan dari pihak terkait dalam hal ini Dinas Kesehatan Kabupaten Gunungkidul.

Penggunaan air sebagai media untuk mencuci sayuran dimungkinkan memiliki pengaruh terhadap terjadinya kontaminasi. Air bersih yang dipakai untuk mencuci sayuran yang digunakan sebagai sayuran mentah (lalapan) di warung makan lesehan di kota Wonosari Gunungkidul, sebagian besar berasal dari air PDAM. Sumber perolehan kebutuhan air bersih dari PDAM tersebut diantaranya berasal dari sumur arthesis dan sungai bawah tanah kemudian diistribusikan kepada masyarakat tanpa disertai dengan pengolahan terlebih dahulu.

Penelitian yang dilakukan oleh Kodijat pada tahun 1988, menunjukkan bahwa sumber kontaminasi juga berasal dari air dan lumpur yang berasal dari PLTA Bandung, yang sepanjang alirannya dipakai untuk menyiram, mencuci dan memupuk tanaman/sayuran. Hasil penelitian tersebut menunjukkan bahwa air $(36,8 \%)$ dan lumpur $(21,0 \%)$ telah tercemar dengan telur $A$. lumbricoides, $T$. trichiura dan cacing tambang dan juga ditemukan adanya larva rhabditiform dan larva filariform. Hal yang sama juga ditunjukkan oleh penelitian yang dilakukan oleh Fauzan pada tahun 1992, bahwa sumber pencemaran telur nematoda usus yakni melalui penyiraman sayuran.

Tidak ditemukannya telur nematoda usus, baik spesies maupun bentuk infektif dan atau bentuk non infektifnya juga dapat disebabkan oleh perlakuan contoh uji sayuran kubis pada waktu sebelum dan saat dilakukannya pemeriksaan. Sebelum dilakukannya pemeriksaan hal yang berpengaruh terhadap ketepatan hasil dapat disebabkan oleh kondisi contoh uji sayuran kubis yang telah dicuci dengan bersih di tingkat pedagang warung makan lesehan, sedangkan pada saat dilakukannya pemeriksaan di laboratorium (tahap analitik) dipengaruhi oleh perlakuan pada saat pengambilan sedimen yang terdapat pada dasar tabung sentrifuge, apabila didalam pengambilan tersebut kurang berhatihati dapat menyebabkan hasil pemeriksaan preparat mikroskopis tidak representatif bahkan kurang berkualitas.

Untuk memperoleh gambaran kontaminasi telur cacing pada sayuran sebaiknya menggunakan gabungan dua teknik pemeriksaan, yaitu teknik sedimentasi dan teknik flotasi, karena telur cacing yang tidak terambil pada dasar tabung sentrifuge pada teknik sedimentasi dapat ditangkap menggunakan deck glass/cover glass saat dilakukan pemeriksaan dengan teknik pengapungan (flotasi).

\section{SIMPULAN DAN SARAN}

\section{a. Simpulan}

Berdasarkan hasil penelitian dapat disimpulkan sebagai berikut:

1) Terdapat kontaminasi telur nematoda usus sebesar $38,89 \%$ pada sayuran kubis (Brassica oleracea) yang digunakan sebagai sayur lalapan mentah pada warung makan lesehan di kota Wonosari Gunungkidul Yogyakarta.

2) Spesies telur nematoda usus yang mengkontaminasi sayuran kubis (Brassica oleracea) yang digunakan sebagai sayur lalapan mentah pada warung makan 
lesehan di kota Wonosari Gunungkidul Yogyakarta, meliputi spesies telur Ascaris lumbricoides (50\%), Cacing tambang (12,5\%) dan Trichuris trichiura $(37,5 \%)$.

3) Bentuk infektif spesies telur nematoda usus yang mengkontaminasi sayuran kubis (Brassica oleracea) yang digunakan sebagai sayur lalapan mentah pada warung makan lesehan di kota Wonosari Gunungkidul Yogyakarta, adalah bentuk infektif spesies telur Ascaris lumbricoides.

b. Saran

Berdasarkan hasil penelitian yang telah dilakukan maka penulis mengajukan saran-saran sebagai berikut :

1) Dinas Kesehatan Kabupaten Gunungkidul

Perlu dilakukan penyuluhan kepada pedagang warung makan lesehan mengenai kontaminasi telur nematoda usus pada sayuran kubis (Brassica oleracea) yang digunakan sebagai sayur lalapan mentah pada warung makan lesehan di kota Wonosari Gunungkidul Yogyakarta.

2) Fakultas Kesehatan Masyarakat UAD

Perlu dilakukan penelitian lebih lanjut mengenai pencemaran nematoda usus dengan metode penelitian deskriptif kuantitatif analitik, seperti mengetahui faktor-faktor perilaku dalam pemanfaatan dan pengolahan sayuran yang dikonsumsi secara mentah.

\section{KEPUSTAKAAN}

1. Yuniastuti, Endang, Dewi, Widyatmani Sih.Program Pengembangan Budaya Kewirausahaan di Perguruan Tinggi : http://lppm.uns.ac.id, diambil pada tanggal 7 Juli 2010, Yogyakarta. 2007

2. Anonim. Manfaat Lalapan Untuk Kesehatan : http://www.prlog.org, diambil pada tanggal 7 Juli 2010, Yogyakarta. 2010a

3. Pracaya.Kol alias Kubis, Penebar Swadaya, Jakarta. 2005

4. Rukmana, R. Seri Budi Daya : Kubis, Penerbit Kanisius, Yogyakarta. 1994

5. Kodijat, S. "Salah Satu Kemungkinan Penyebab Kontaminasi Sayuran Mentah dengan Cacing-Cacing yang Ditularkan Melalui Tanah". Abstrak Makalah Dalam Prosiding Seminar Parasitologi Nasional V, Perkumpulan Pemberantasan Penyakit Parasit Indonesia. Jakarta. 1988

6. Depary, A.A. "Helminthiasis Intestinal Di Kalangan Mahasiswa-Baru suatu Akademi Keperawatan Di Medan". Majalah Kedokteran Nusantara, Medical Journal Of The University Of North Sumatra, Vol. XXIX No. 2 Juni 1999, Hal : 19 - 21, Fakultas Kedokteran Universitas Sumatera Utara, Medan.1999

7. Gandahusada, S., H, Herry D. Ilahude, Wita Pribadi. Parasitologi Kedokteran, Gaya Baru, Jakarta. 2003

8. Noor, N. N. Pengantar Epidemiologi Penyakit Menular, Rineka Cipta.Jakarta.2006

9. Gillespie, H. S., Richard D. Pearson. Principles and Practice of Clinical Parasitology, John Wiley \& Sons Ltd, USA. 2001

10. Brown, W., H.,Dasar Parasitologi Klinis, PT. Gramedia , Jakarta. 1983

11. Sehatman."Diagnosa Infeksi Cacing Tambang", Majalah Media Penelitian Dan Pengembangan Kesehatan, Volume XVI No. 4 / 2006, Hal : 22 - 25, Badan Penelitian dan Pengembangan Kesehatan Departemen Kesehatan RI, Jakarta. 2006 